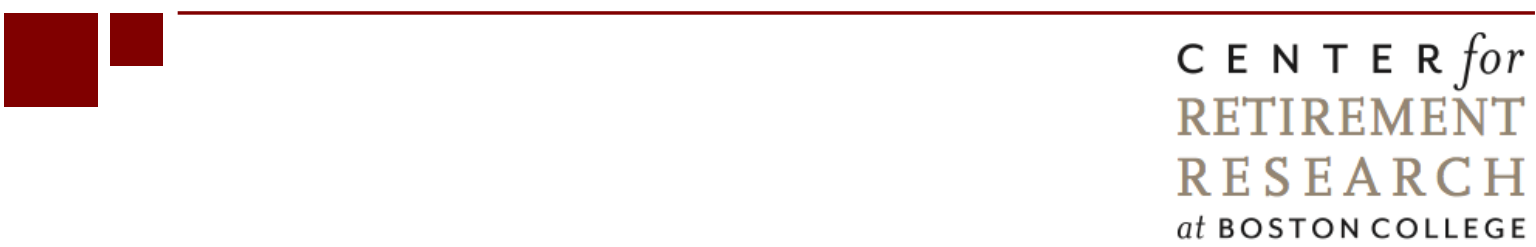

\title{
HOW WOULD INVESTING IN EQUITIES HAVE AFFECTED THE SOCIAL SECURITY TRUST FUND?
}

\author{
Gary Burtless, Anqi Chen, Wenliang Hou, and Alicia H. Munnell \\ CRR WP 2016-6 \\ July 2016 \\ Revised: May 2017
}
Center for Retirement Research at Boston College
Hovey House
140 Commonwealth Ave
Chestnut Hill, MA 02467

Tel: 617-552-1762 Fax: 617-552-0191

http://crr.bc.edu

Gary Burtless is the John C. and Nancy D. Whitehead Chair in Economic Studies at the Brookings Institution. Anqi Chen is a research associate at the Center for Retirement Research at Boston College (CRR). Wenliang Hou is a senior research advisor at the CRR. Alicia H. Munnell is the Peter F. Drucker Professor of Management Sciences at Boston College's Carroll School of Management and director of the CRR. The research reported herein was performed pursuant to a grant from the U.S. Social Security Administration (SSA) funded as part of the Retirement Research Consortium. The opinions and conclusions expressed are solely those of the authors and do not represent the opinions or policy of SSA, any agency of the federal government, the Brookings Institution, or Boston College. Neither the United States Government nor any agency thereof, nor any of their employees, makes any warranty, express or implied, or assumes any legal liability or responsibility for the accuracy, completeness, or usefulness of the contents of this report. Reference herein to any specific commercial product, process or service by trade name, trademark, manufacturer, or otherwise does not necessarily constitute or imply endorsement, recommendation or favoring by the United States Government or any agency thereof.

(c) 2016, Gary Burtless, Anqi Chen, Wenliang Hou, and Alicia H. Munnell. All rights reserved. Short sections of text, not to exceed two paragraphs, may be quoted without explicit permission provided that full credit, including (C) notice, is given to the source. 


\begin{abstract}
About the Center for Retirement Research
The Center for Retirement Research at Boston College, part of a consortium that includes parallel centers at the University of Michigan and the National Bureau of Economic Research, was established in 1998 through a grant from the Social Security Administration. The Center's mission is to produce first-class research and forge a strong link between the academic community and decision-makers in the public and private sectors around an issue of critical importance to the nation's future. To achieve this mission, the Center sponsors a wide variety of research projects, transmits new findings to a broad audience, trains new scholars, and broadens access to valuable data sources.
\end{abstract}

Center for Retirement Research at Boston College

Hovey House

140 Commonwealth Ave

Chestnut Hill, MA 02467

Tel: 617-552-1762 Fax: 617-552-0191

http://crr.bc.edu

Affiliated Institutions:

The Brookings Institution

Massachusetts Institute of Technology

Syracuse University

Urban Institute 


\begin{abstract}
Restoring balance to the Social Security system will require raising taxes, reducing benefits, or both. Some observers believe that investing a portion of the Social Security Trust Fund in equities, as part of a comprehensive reform package, could strengthen its finances and improve the program's intergenerational risk-sharing. However, equity investments would also expose the program to greater financial risk and potentially greater political risk. The analysis examines retrospectively using observed returns and prospectively using Monte-Carlo simulation methods, whether equity investments would likely strengthen the long-term outlook of the Trust Fund relative to the current policy of investing 100 percent of reserves in U.S. government bonds. A welfare analysis is also conducted to address the contention that workers will not value lower taxes in good times as much as they dislike tax hikes in bad times. The issues surrounding equity investments also go beyond expected returns on the Trust Fund portfolio. Concerns of government interference with the allocation of capital in the economy and with corporate decision-making as well as the accounting treatment of equity investments are also discussed.
\end{abstract}

This paper found that:

- Both prospective and retrospective analyses suggest that investing a portion of the Social Security Trust Fund in equities would improve its finances.

- Little evidence exists that Trust Fund equity investments would disrupt the stock market.

- Accounting for returns on a risk-adjusted basis would not show any up-front gains from equity investment, but gains would become evident over time if higher returns were realized.

- Equity investments could be structured to avoid government interference with capital markets or corporate decision-making.

The policy implications of this paper are:

- Investing a portion of trust fund assets in equities would likely reduce the need for higher payroll taxes or benefit cuts.

- At the $50^{\text {th }}$ percentile of outcomes, equity investing has the potential to maintain a healthy Trust Fund ratio through the 75-year period.

- The experience with the Thrift Savings Plan provides a road map for separating the government from actual investment decisions. 


\section{Introduction}

By increasing the expected rate of return on asset holdings, investing part of Social Security's reserves in equities can strengthen the long-term financial outlook of the program. Some advocates of this policy also believe it would improve intergenerational risk-sharing. By increasing the variance of annual returns on Trust Fund holdings, however, the policy shift would also expose the program to greater financial risk and potentially to greater political risk.

This paper evaluates the implications of investing part of the Trust Fund in equities using two simulation approaches. First, it uses actual historical returns on equity investments to investigate whether, with the benefit of hindsight, it would have appeared advantageous to invest a portion of the Trust Fund in equities starting in 1984 and in 1997. The first year followed the enactment of the 1983 Social Security amendments, which put the program on a course to accumulate large Trust Fund reserves over the next three decades. The latter year followed the Report of the 1994-96 Advisory Council, which included a variety of proposals for equity investments, either inside the Trust Fund or in a modified retirement system that included individual investment accounts. Second, it analyzes the Social Security outlook under the assumption that policymakers in 2017 act to restore long-run solvency by increasing the payroll tax. This policy would dramatically increase future Trust Fund balances compared with those expected under current law. Monte-Carlo simulation methods are used to investigate whether investing in equities would strengthen the long-term outlook compared with the current policy of investing 100 percent of reserves in U.S. government bonds.

These simulations suggest that equity investments would have been helpful historically and would be helpful prospectively. However, the issues surrounding equity investment transcend the expected return on the Trust Fund's investment portfolio. Thus, the fears of opponents about government interference with the allocation of capital in the economy and with corporate decision-making are also discussed. An issue also arises with regard to accounting for the higher expected returns (and greater risk) of equity investment when analyzing the long-run outlook for the program.

The discussion proceeds as follows. The first section provides background on the debate over investing Trust Fund reserves in equities. The second section discusses the case for equity investment. The third section describes the data and methodology underlying the analysis 
of the impact of equity investment on Trust Fund balances. The fourth section presents the results. The fifth section discusses other experiences of government entities holding equities in their investment portfolios. The sixth section assesses the impact of equity investment on government finances. The final section summarizes the conclusions. Both prospective and expost analyses show that an allocation to corporate equities would have improved Social Security finances. In addition, little evidence exists that such investment would disrupt the stock market. Whether equity investment would adversely affect corporate governance depends crucially on the rules that Congress adopts regarding voting the equity shares held by the Trust Fund.

\section{The Origins of the Equity Debate}

Policymakers have long known that the retirement of the Baby Boom generation would result in a sizeable rise in Old-Age and Survivors Insurance recipients and had the potential to create major financial problems for the program. A sharp increase in the ratio of old to young boosts the cost of Social Security. Currently, the combination of a rising cost rate and a stable income rate produces cash-flow deficits over the program's 75-year projection period. In 1983, the combination of a long-run deficit and the immediate prospect of being unable to pay benefits led Congress to enact changes that raised revenues and reduced benefits.

By the 1990s, significant long-term imbalances re-emerged (see Figure 1). President Clinton asked the 1994-96 Social Security Advisory Council to consider options to achieve longterm solvency. The Council could not agree on a single plan, so its members advanced three different plans to close the funding gap. All three plans included some form of investment in corporate equities to boost returns on Social Security contributions. Two of the three plans proposed that equity investment take place in individually held private accounts. The third plan recommended that a fraction of the Trust Fund reserves be invested directly in equities. President Clinton later proposed that a modest portion of reserves could be invested in equities, but Congress did not act on this proposal.

\section{The Case for Equity Investment}

Investment in equities could have three important advantages. First, equities offer investors a higher expected rate of return relative to safer assets, such as Treasury bills or bonds. Table 1 shows the geometric mean return on the Standard and Poor's 500 stock index between 1928 and 
2015 was 9.5 percent. In comparison, the mean return on 3-month Treasury bills was just 3.5 percent and that on 10-year U.S. Treasury bonds was 5.0 percent. In exchange for higher returns, of course, equities carry greater risk. The standard deviation of S\&P 500 annual returns was 19.8 percent, versus just 3.1 percent for Treasury bills and 7.8 percent for 10-year Treasury bonds. For many long-term investors, however, the sizeable equity premium may make the extra risk tolerable. Investors who bought $\$ 100$ of stocks on the first day of 1928 and steadily reinvested dividends in a S\&P 500 index fund for the next 88 years would have slightly more than $\$ 294,000$ at the end of 2015. In contrast, an investor who bought $\$ 100$ in 10-year Treasury bonds on the same day in 1928 and steadily reinvested interest payments in bonds would have held just $\$ 7,062$ at the end of 2015. Past returns are not a guarantee of future performance, but these differences in mean returns as well as variances around mean returns have persisted for long periods.

The second potential advantage of equity investment in the Trust Fund is improvement in intergenerational risk-sharing. ${ }^{1}$ In general, efficient risk-sharing requires individuals to bear more financial risk when young and less when old. Some argue that it is easier for the young to work more in the event they suffer a capital loss. They can also average returns over time and take advantage of the fact that declines in stock prices are often associated with higher returns in following periods. But even if stocks do not display "mean reversion,” a case can be made for holding more stocks when young based on the expected pattern of labor earnings as workers grow older. The best way for most people to stabilize the risk in their portfolio as they age is to reduce equity holdings as a share of their total portfolio as the number of future periods to earn labor income declines.

Because they have not yet accumulated much financial wealth, the young typically hold no risky, high-yielding financial assets. One important asset that they do hold is a growing claim on future Social Security benefits. Because of the current Trust Fund investment policy, however, this asset is invested solely in safe, low-expected return Treasury bonds. Shifting Social Security asset holdings from low-risk, low-return bonds to higher risk, high-expectedreturn equities would shift some financial market risk from the old to the young. This change improves the age distribution of risk and could make all generations better off.

\footnotetext{
${ }^{1}$ Bohn (1999 and 2009), Diamond et al. (1997), and Gollier (2008).
} 
Gollier (2008) demonstrates that the expected real return could be raised by 100 basis points from such intergenerational risk-sharing. The gain comes because a better sharing of risks across generations makes it efficient to invest more in risky assets and thereby gain from the equity premium without increasing the risk at the individual household level. The challenge is that unless the contract is well specified - that is, participants know the exact rules of the game and can be assured that some mechanism will prevent decade after decade of bad experience - they will not be willing to continue to participate. And once rules are imposed - that the insurance fund remain solvent and workers receive a guaranteed minimum return on their contributions the potential gains from spreading risks over generations are reduced somewhat, but remain positive and substantial.

The third argument in favor of equity investment is more political than economic. If the Trust Fund actually earns higher real returns, close to those earned on equity investments in the past, Social Security would be less expensive in the future because a larger share of benefit claims could be financed out of investment income. This result could reduce political pressure to cut benefits, increase taxes, or fundamentally change the cross-generational political compact that sustains the program. By making Social Security benefits less expensive, the addition of equity investments to the portfolio could thus reduce political risk to the program.

Equities can thus offer a promising way forward, because of the high expected returns on stocks and the diversification of the program's funding sources beyond the payroll tax, taxation of benefits, general fund reimbursements, and investment income on bonds. Despite these advantages, skeptics have questioned the wisdom of direct government investment in the stock market. One concern is the risk that Social Security stock holdings might become large enough to threaten the stability of the stock market. Another is that Trust Fund share ownership might result in undue government influence over corporate decision-making. Finally, the volatility of stock market returns poses a risk that the Trust Fund could be exhausted earlier than if all of the reserves continue to be invested in low-risk Treasury securities.

\section{Equity Investment and Social Security Finances}

This paper addresses two basic questions: How would investing in equities have affected the finances of Social Security if the policy had been adopted in the past? How would the program's future finances be affected if the policy were adopted as part of an overall package to 
restore solvency over the next 75 years? After the early 1960s, Social Security had no more than a buffer Trust Fund. That situation persisted up until the 1983 reforms, when Congress and the President increased taxes and reduced benefits, producing a period of cash surpluses for Social Security. One plausible starting point for the analysis is therefore 1984, when the new Trust Fund accumulation policy went into effect. Another plausible starting date is 1997, the year immediately after the 1994-96 Advisory Council recommendations.

The impact of equity investment on Social Security finances can be examined in two ways: 1) alternative Trust Fund trajectories based on ex-post returns; and 2) a probabilistic range of Trust Fund trajectories based on the historical range of equity and bond returns up to the point of the policy change. The option of investing part of the Trust Fund in equities may also be considered if and when Congress moves to restore financial balance to the system. To evaluate this option, the analysis assumes that payroll taxes are raised immediately by enough to close the 75-year funding gap. This policy will produce large and growing Trust Fund accumulations during the first decades of the projection period, even if 100 percent of the reserve is held as Treasury securities. ${ }^{2}$ Introducing equity investments offers the potential to maintain a healthy Trust Fund balance over the full projection period.

\section{The Data}

Modeling Social Security finances requires data on the income and cost components of the Trust Fund as well as data on equity returns and intermediate-term U.S. Treasury securities. Income and cost components of the combined Old-Age Survivors and Disability Insurance (OASDI) Trust Fund, both historically and for the 75-year projection horizon, are reported in the 2015 Social Security Trustees Report. ${ }^{3}$

Historical equity returns are based on reported returns of the Wilshire 5000 and the Ibbotson Large Cap Index. While the Wilshire 5000 is a better measure of total market returns than the S\&P 500 or Ibbotson Large Cap Index, it only goes back to 1971. To infer annual Wilshire 5000 returns before 1971, the statistical relationship between the Wilshire 5000 and the Ibbotson Large Cap index - during the period in which they were both available, 1971-2015 - is

\footnotetext{
${ }^{2}$ See U.S. Social Security Administration (2015) for estimates on the effect of investing 40 percent of the OASDI Trust Fund in equities without a tax increase.

${ }^{3}$ See Table VI. A1, Table VI. A3, and Table VI. G8 from the 2015 Social Security Trustees Report. Since the DI Trust Fund was established in 1958, between 1937 and 1958 the data refer to the OASI Trust Fund.
} 
estimated. Small capitalization stocks tend to outperform large-cap equities over long time horizons. As a result, the Wilshire 5000, which includes both small- and large-cap stocks, outperformed the Ibbotson Large Cap Index. This out-performance is assumed to be constant and applied to the Ibbotson Large Cap Index for the period 1929-1971 to create a hypothetical sequence of Wilshire 5000 returns in those earlier years. ${ }^{4}$

\section{Trust Fund Accounting}

Trust Fund assets in each year are:

$$
A_{t}=I_{t}^{N}+I_{t}^{I}-C_{t}+A_{t-1}
$$

where $A_{t}$ represents assets at the end of year $t, I_{t}^{N}$ is non-investment income, $I_{t}^{I}$ is investment income, $C_{t}$ is the total cost of the program for that year, and $A_{t-1}$ is assets at the end of the previous year. Currently the Trust Fund invests solely in Treasury securities. ${ }^{5}$ Investment income is thus the effective interest rate on special-issue Treasury bonds payable on the Trust Fund in year $t$ multiplied by assets from the previous year, $A_{t-1}$.

When equities are introduced, investment income becomes:

$$
I_{t}^{I}=\left(p_{t} \times A_{t-1}\right) r^{E}+\left(\left(1-p_{t}\right) \times A_{t-1}\right) r^{B}
$$

where $r^{E}$ represents the return on equities in year $t$ and $r^{B}$ the effective interest rate on specialissue Treasury bonds held by the Trust Fund. ${ }^{6}$ The return on equities is based on the actual and hypothetical Wilshire 5000 series described above.

The proportion of Trust Fund assets invested in equities, $p_{t}$ depends on the phase-in scheme adopted and the assumed ceiling on equity holdings. The central assumptions follow the "Maintenance-of-Benefits" proposal outlined in the 1994-96 Social Security Advisory Council report. Starting in the year of implementation of this proposal, the percentage of Trust Fund reserves invested in equites would increase by 2.67 percentage points each year up to a ceiling equity allocation of 40 percent. $^{7}$ Therefore, the percent of total assets in equities is:

\footnotetext{
${ }^{4}$ Although small-cap equities have outperformed large-cap equities, the Wilshire 5000 is comprised of approximately 10 percent small-cap equities and 90 percent large-cap equities on an asset-weighted basis. Therefore, the Wilshire 5000 tracks closely with the Ibbotson Large Cap Index.

${ }^{5}$ Non-interest income is comprised of payroll taxes, taxes on benefits received, and general fund reimbursements.

${ }^{6}$ Due to differing maturity dates, the effective interest rates (or expected effective interest rates) earned on specialissue Treasury bonds differ from the average interest rate. The ex-post analysis uses effective interest rates. See https://www.ssa.gov/oact/progdata/annualinterestrates.html for more information.

${ }^{7}$ Alternative equity accumulation rates of 2.0 and 5.0 percentage points per year, as well as equity allocation caps of 20 percent and 60 percent of total assets, were also modeled.
} 


$$
p_{t}=\min [0.0267 t, 0.4]
$$

\section{Monte-Carlo Simulations}

Evaluating the strategy of investing a portion of the Trust Fund in equities requires weighing the higher-risk/higher-return characteristics of equities against the risk of prematurely depleting the Trust Fund. The uncertainty centers on the future returns on bonds and stocks.

A Monte-Carlo analysis with 10,000 simulations is used in order to project the range of outcomes for equity and bond returns. Equity returns are assumed to follow a lognormal distribution while bond returns are constructed from interest rates on new special issues, which follow an autoregressive model. ${ }^{8}$ The covariance between interest rates on new special issues and equity returns is assumed to be zero. ${ }^{9}$ For simplicity, equity mean-reversion is not incorporated in the model. ${ }^{10}$

Future Equity Returns. The simulations assume that Congress introduces equity investment in 2017 as part of a package to restore balance to the system. A question arises as to what mean equity return should be projected for the next 75 years relative to the historical mean return observed through 2015. Using historical returns would lead to unprecedented ratios of total stock market value to U.S. gross domestic product. In addition, many observers believe equity returns will be lower in the future than in the past. ${ }^{11}$ To get some idea of future real returns, three approaches are considered. The first is simply to look at the inverse of the price/earnings (P/E) ratio to gauge future returns, which at 25.8 suggests future real returns of 3.9 percent. ${ }^{12}$ Shortterm earnings yields, however, can be misleading. Campbell and Shiller (1988) argue that the

\footnotetext{
${ }^{8}$ An ARIMA $(1,0,1)$ model was used.

${ }^{9}$ The Social Security Trust Fund invests in special-issue Treasury bonds that are only available to the Trust Fund and are redeemable at par. The covariance between equity returns and the interest rate on these special-issue bonds has historically been zero, so the same is assumed for the simulations.

${ }^{10}$ Poterba and Summers point out that if returns were independent and identically distributed (IID), the variance of the $n$ period return ought to be root(n) of the one-period return. They find that the variance of the eight-year return is only 57 percent as large. But their statistical tests do not permit them to distinguish between mean reversion and the effects of changes in required returns resulting from fluctuations in interest rates and market volatility. Fama and French (1988) investigate the autocorrelation of stock returns. They find that these are negative for two-year returns, reach minimum values at three- to five-year returns, implying mean reversion, and then move back to zero. But their estimates of long-run mean reversion are imprecisely estimated, and it is also unclear whether the degree of mean reversion has changed over time. As the focus of our analysis is on the performance of the Trust Fund over long time horizons, and as it is unclear what alternative assumption would be most appropriate, IID returns are assumed throughout our analysis.

${ }^{11}$ Campbell and Shiller (1998), Diamond (1999), Siegel (1998).

${ }^{12}$ Refers to the P/E ratio for the Wilshire 5000 as of December 2016.
} 
10-year earnings yield is a much better predictor of the return on stocks. The current cyclically adjusted PE (CAPE) ratio is 28.7, which suggests a future long-term real stock return of 3.5 percent. ${ }^{13}$

The third approach turns to a formula from the Gordon growth model, which establishes a steady state relationship between market value, stock returns, and GDP. The Gordon formula says that stock returns equal the ratio of adjusted dividends to prices (the adjusted dividend yield) plus the growth rate of stock prices. ${ }^{14}$ In a steady state, the growth rate of stock prices can be assumed to equal the growth rate of GDP. Assuming a dividend yield of roughly 2.1 percent (Shiller 2016) and projected GDP growth of 2.2 percent, the stock return implied by the Gordon equation is 4.3 percent.

The results of these three simple exercises suggest future real returns ranging from 3.5 to 4.3 percent. ${ }^{15}$ For simplicity, future nominal equity returns at the $50^{\text {th }}$ percentile are assumed to equal 3.9 percent, the mid-point of the range.

Future Bond Returns. Social Security's Office of the Chief Actuary provides projections on both the rates on new special-issue bonds and the effective realized returns on the Trust Fund for the 75-year projection period. ${ }^{16}$ However, to ensure the symmetric treatment of returns on both kinds of asset, future interest rates on new special issues are also simulated. As with future equity returns, a question arises on the suitability of projecting future bond interest rates based on a fitted historical distribution.

The first concern is the possible correlation between the timing of bond sales or purchases and bond interest rates. Years with exceptionally high equity returns will force the managing Trustee to sell stocks and buy bonds; years with low equity returns will force the manager to buy stocks and sell bonds. If years that require bond purchases have, on average, lower bond interest rates than years that require bond sales, simulations based on random draws from historical interest rates could overestimate future bond yields. In other words, the Trust

\footnotetext{
${ }^{13}$ The CAPE provided by Robert J. Shiller is as of February 2017.

${ }^{14}$ The adjusted dividend yield is the dividend yield plus net shares repurchased.

${ }^{15}$ The Trustees predict that annual CPI-W inflation will average 2.7 percent from 2016-2090.

${ }^{16}$ The average special-issue interest rate for a calendar year is the average of the 12 monthly interest rates on new issues during the year. The effective interest rate for a calendar year is the interest earned in that year divided by the average level of assets held during the year.
} 
Fund may be selling higher yielding bonds in years with liquidity shortfalls but buying lower yielding bonds in years with excess liquidity.

The second concern is that investment policy and hence the maturity structure of the bond portfolio held by the Trust Fund has fluctuated considerably over time, ranging from bonds with durations of a year or less to the current policy of spreading the maturities of newly purchased bonds equally over a 15-year period. If the current bond management policy is assumed to continue over the projection horizon, the historical distribution of market returns on Treasury securities will not be appropriate for predicting future annual returns. It therefore makes sense to simulate the bond interest rate on new special Treasury issues rather than the effective yield on the bond portfolio. The effective yield on the bond portfolio will then be the weighted average of interest rates on past special Treasury issues, with the weights determined by the share of the bond portfolio that was purchased in each of the past 15 years.

Construction of Bond Returns. As noted, the Monte-Carlo simulations use the interest rates, $r_{t}^{B}$, on new special-issue Treasury securities purchased by the Trust Fund during a calendar year. These rates are independent of the timing of portfolio rebalancing and evolving investment policies. ${ }^{17}$

The effective (realized) return $I_{t}^{B}$, is the sum of interest earned on all bonds held in the portfolio (that is, purchased over the previous 15 years) and $P_{t}$ is the amount of new bond purchases at time $t$.

$$
I_{t}^{B}=\left(P_{t-1} \times r_{t-1}^{B}\right)+\frac{14}{15}\left(P_{t-2} \times r_{t-2}^{B}\right)+\ldots+\frac{1}{15}\left(P_{t-15} \times r_{t-15}^{B}\right)
$$

Since the special-issues can always be redeemed at par, the value of bonds maturing in year $t$, $M_{t}$, is:

$$
M_{t}=\frac{P_{t-1}+P_{t-2}+\ldots+P_{t-15}}{15}
$$

The cash available for new investment is thus:

$$
L_{t}=I_{t}^{N}-C_{t}+I_{t}^{B}+I_{t}^{E}+M_{t}
$$

\footnotetext{
${ }^{17}$ The interest rate on new special-issues in a given month is the average market yield on marketable interest-bearing securities of the Federal government with maturities of four or more years. This interest rate is assigned to all the special-issue securities purchased in a month, regardless of the maturity of the security. One-fifteenth of the securities purchased are assigned a maturity of one year, one-fifteenth are assigned a maturity of two years, and so on up through an assigned maturity of 15 years.
} 
Trust Fund assets and the net increase in assets are defined as $A_{t}$ :

$$
A_{t}=A_{t-1}+L_{t}-M_{t}
$$

Recall that the equity allocation is phased in by increasing the percentage of the Trust Fund invested in equites by 2.67 percentage points each year up to a ceiling allocation of 40 percent. $^{18}$

$$
p_{t}=\min [0.0267 t, 0.4]
$$

The investment allocation of the Trust Fund is rebalanced at the end of each year after accounting for realized returns from equity and bond investments $E_{t}$ and $B_{t}$ respectively.

$$
\begin{aligned}
& E_{t}=p_{t} A_{t} \\
& B_{t}=\left(1-p_{t}\right) A_{t}
\end{aligned}
$$

If additional cash available for investment minus the change in equity investments is positive, this difference would equal the new bond purchases, $P_{t}$, in a given year, with maturities spread evenly across the next 15 years.

$$
P_{t}=\max \left[0, L_{t}-\left(E_{t}-E_{t-1}\right)\right]
$$

If, instead, the difference between cash and the change in equities is negative, then the Trust Fund will need to sell bonds to finance operations and equity purchases. In years when bonds must be sold in order to pay for Social Security operations and equity purchases, the managing Trustee is assumed to sell an equal fraction of bonds across all the maturity tranches. In other words, bond sales will not be conducted in a way that would boost the yield on the portfolio (for example, by selling low-yielding bonds before high-yielding bonds).

\section{Results}

The following results provide answers to two questions: 1) Based on ex-post equity returns and bond interest rates, what would have been the outcome if the Trust Fund had begun investing in equities in 1984 and 1997?; and 2) What array of outcomes could policymakers foresee if they shifted to equity investment in 2016?

\footnotetext{
18 There are two main approaches to portfolio rebalancing. The first is periodic rebalancing, where a portfolio manager will review current investment allocations periodically (i.e. weekly, monthly, annually) to bring the portfolio back to target. The second is tolerance band rebalancing, where portfolio managers will rebalance every time an asset class deviated outside a pre-determined tolerance band. The Thrift Savings Plan uses daily periodic rebalancing. The Canadian Pension Plan uses tolerance bands of $10 \%$ for all asset types. For simplicity, the Trust Fund is assumed to be rebalanced annually at the end of each year.
} 


\section{Equity Investing in Hindsight}

Actual historical returns are used to determine whether, with the benefit of hindsight, investing the Trust Fund in equities would have improved Trust Fund solvency in 2015. Unsurprisingly, given strong historical average annual returns, investing a portion of the Trust Fund in equities would have increased the balance, regardless of whether investments began in 1984 or 1997. The decline in equity values during the financial crisis has been more than offset by the robust returns after March 2009. If equity investment had started in 1984, Trust Fund assets in 2015 would have been \$3.8 trillion compared to actual holdings of \$2.8 trillion. The comparable figure for starting in 1997 would have been \$3.4 trillion.

These results can also be expressed in terms of the Trust Fund ratio, the assets in the fund at the beginning of the year divided by spending during the year. A Trust Fund ratio of 1.0, which means that the fund's reserves can cover a year of anticipated outlays, is the benchmark used by the Trustees to determine whether the fund meets the short-term test of financial adequacy. If equity investment had started in 1984, the Trust Fund ratio in 2015 would have been 4.1 compared to an actual ratio of 3.1. If equity investment had started in 1997, the ratio would have been 3.7. This exercise was repeated using longer and shorter equity phase-in periods (see Table 3) and higher and lower ceilings on equity holdings (see Table 4), and the basic results changed little. Investment strategies with shorter phase-in periods allowed for quicker asset accumulation. This pattern also applied to strategies with higher equity ceilings; however, higher ceilings also resulted in larger losses during the financial crises. ${ }^{19}$ Despite these differences, had equity investments been introduced in 1984 or 1997, robust equity returns since the crises yield higher Trust Fund ratios in 2016 regardless of the length of phase-in or the equity ceiling. ${ }^{20}$

\section{Equity Investment Starting in 2017}

Looking forward, the assumption is that policymakers restore long-run solvency by raising the payroll tax by enough to eliminate the 75-year deficit ( 2.58 percentage points). Long-run equity returns for this exercise are centered at 6.78 percent, which is equal to 6.95

\footnotetext{
19 This result holds even under the extreme policy example of no equity phase-in. That is, 40 percent of the Trust Fund is immediately invested in equities. The results are shown in Figure A4.

${ }^{20}$ Figures A1, A2, and A3 in the Appendix section illustrates how different equity phase-in and equity ceiling policies would have affected the Trust Fund ratio.
} 
percent (the mid-point in the range of future equity returns) minus 0.17 percent (the difference in inflation from the historical and projection periods).

The key result is that the $50^{\text {th }}$ percentile of outcomes for the mixed portfolio projects a Trust Fund ratio of close to 3.3 at the end of the 75-year period, well above the Trust Fund's short-term benchmark ratio of 1.0 (see Figure 2). Interestingly, even the $25^{\text {th }}$ percentile of the mixed portfolio remains above this short-term benchmark and shows a much better outcome than any of the bond-only simulations depicted. The mixed portfolio also does a much better job of avoiding bad outcomes over the 75-year horizon. Only 22 percent of all simulations for the mixed portfolio ever fall below a Trust Fund ratio of 1.0, and only 10 percent of all simulations end in Trust Fund exhaustion (see Figure 3). ${ }^{21}$ Even when centering our equity return assumptions to 3.5 percent, the $25^{\text {th }}$ percentile of the mixed portfolio is still comparable to the $95^{\text {th }}$ percentile of the bond-only simulations. ${ }^{22}$

The only time that the mixed portfolio performance lags behind the bond-only alternative is in a comparison of the worst possible outcomes. In this case, the Trust Fund under the mixed portfolio is exhausted in 2064, eight years earlier than the comparable outcome under the bondonly portfolio (see Table 5). However, when examining the full distributions of the simulations at the end of the 75-year period, it is extraordinarily rare for the mixed portfolio to have a worse result than the bond-only portfolio. The likelihood that the mixed portfolio is exhausted but the bond-only portfolio is not occurs in only 3.1 percent of the 10,000 simulations. Similarly, on the flip side of the coin, the likelihood that the bond-only portfolio is exhausted but the mixed portfolio is not occurs in 45.3 percent of the 10,000 simulations. The above exercises suggest that investing up to 40 percent of Trust Fund assets in equities could improve Social Security finances and reduce the need for raising employee and employer payroll taxes. If equity investment had begun in 1984 or 1997, Trust Fund assets would be higher than they are currently, despite two major financial crises. Going forward, equity investment could help maintain a healthy Trust Fund ratio through the 75-year period.

\footnotetext{
${ }^{21}$ For simulations in which the Trust Fund is exhausted, the simulation is halted at the point of exhaustion.

${ }^{22}$ See Figures A5 and A6 in the Appendix section for equity returns centered on 3.5 percent and 4.3 percent, respectively.
} 


\section{Equity Investment and Welfare}

A concern with distributional analyses, such as Monte-Carlo, is that it does not accurately reflect the effect of extremely poor equity returns. In these unlikely but still probable events, the harm to workers and retirees may be substantial. Put differently, workers may not value the strong equity performances and lower required taxes from the frequent good outcomes as much as they will dislike the poor equity returns and higher taxes from the few awful outcomes. This might be especially true if these very bad outcomes occur when the economy is in terrible shape. Addressing such a concern requires a welfare analysis.

The analysis starts with calculating the higher "tax refunds" and the higher "back-tax payments” associated with moving from a bond-only portfolio to a mixed portfolio. This is done by calculating the aggregate accumulated surplus or deficit at the end of each of the 10,000 simulations relative to the trust fund's short-term benchmark ratio of 1 . An accumulated surplus or deficit would be distributed equally among the covered workers in 2091 - the $75^{\text {th }}$ year of the projection period - as tax refunds or back-taxes respectively.

As shown in Figure 4, workers would gain \$48,444 in tax refunds at the 50th percentile outcome in Figure 3, but would have to pay $\$ 4,971$ more in back taxes at the 1st percentile (one of the worst outcomes). Workers with a diminishing marginal utility of consumption, however, do not value tax refunds as much as they dislike paying back taxes. ${ }^{23}$ To account for this effect, the dollar amounts are weighted by the marginal utility derived from a CRRA utility function with risk-aversion. ${ }^{24}$ This weighting narrows the gap between the gains and losses, as shown by the second cluster of bars (Figure 4). Since back taxes are more likely to occur when the economy is bad, the amount is then re-weighted assuming that the average wage is halved. Even this dramatic assumption shows tax refunds at the median will still outweigh losses when poor returns occur during a bad economy. Critics, however, have some concerns that the government investing in equities could affect the flow of capital in the economy and corporate activity.

\footnotetext{
${ }^{23}$ Workers are assumed to earn the average wage from and face a 25 percent tax rate. There are no bequest motives. The analysis assumes a risk-aversion coefficient, gamma, equal to two. Sensitivity tests show that once gamma approaches five, individuals are indifferent between the two investment policies. Chetty (2006) however, shows that the wage elasticity of labor supply implies that gamma is bound by an upper limit of two.

24 The weights are relative to the marginal utility of the average after-tax wage when there are no tax-refunds or back taxes. This is represented by: $\frac{[(1-t) W+r]^{(1-\gamma)}}{[(1-t) W]^{(1-\gamma)}}$, where $t$ is the tax rate, $W$ is the average wage, $r$ is the tax refund or required back-taxes, and $\gamma$ is the risk-aversion coefficient.
} 


\section{Impact on Capital Allocation and Corporate Decision-Making}

The impact of Social Security equity investment on capital markets and corporate decision-making depends on the percentage of the total U.S. equity market held in the Social Security Trust Fund and on the rules that Congress imposes on Social Security trustees with regard to voting the shares held in the Trust Fund.

\section{Social Security's Share of the Stock Market}

Figures 4 and 5 show the percentage of the stock market that Social Security would have owned retrospectively and prospectively. If Social Security had begun investing in the stock market in 1984 or 1997, it would own less than 10 percent of the market today (see Figure 5). This finding also holds prospectively (see Figure 6).

If the Social Security payroll tax were raised by 2.58 percentage points and a portion of the Trust Fund invested in equities, the Trust Fund's share of the total stock market would increase as equity holdings climbed toward 40 percent of assets. In most outcomes, once the fund reached its 40-percent limit, Social Security’s share of total equities would start to decline. Thus, it appears that equity markets would grow fast enough to absorb the equity investment envisioned in this analysis.

\section{Government Investment in the Stock Market}

The size of the equity investment is one issue. Another issue is how government officials are likely to vote the corporate shares purchased if the Trust Fund portfolio included equities. Issues of corporate governance may be contentious and are a distraction from the purpose of Social Security. It may thus be judicious for Congress to hand over responsibility of voting the Trust Fund shares to a separate entity. The question then becomes whether effective mechanisms can be established to ensure that the government does not interfere in private sector decisions.

Proponents of Trust Fund equity investment who served on the 1994-96 Social Security Advisory Council assumed that the government would take a passive role in selecting and voting company shares held in the Trust Fund. They suggested that investments match or track a broad market index, such as the Wilshire 5000, Russell 2000, or Standard and Poor's Composite 1500. They also proposed to legally require investment neutrality. To achieve these objectives, the government could establish an expert investment board similar to the Federal Retirement Thrift 
Investment Board, which administers the Thrift Savings Plan for federal employees. This board would be responsible for selecting a broad market index and for choosing, through competitive bidding, several portfolio managers to manage the accounts, and for monitoring the performance of these managers. In response to concerns about government interference in corporate decisionmaking, the Trust Fund shares could either not be voted or voted in a pattern that reflects the votes of other common shareholders. An alternative is to delegate voting decisions to the individual portfolio managers, which is the practice of the Thrift Savings Plan.

One question is whether these safeguards or other arrangements would avoid government interference in the private market. Two examples are available.

U.S. Federal Thrift Savings Plan. Francis Cavanaugh, the first executive director of the Federal Retirement Thrift Investment Board for the Thrift Savings Plan, was an official in the U.S. Department of the Treasury in 1988 when the Treasury Department opposed Social Security Trust Fund investment in equities. After eight years investing Federal employee monies in equities, however, he changed his mind (Cavanaugh 1997). He reported that the Board encountered no difficulties in selecting an index and obtaining competitive bids from large index fund managers. At the beginning of 2015, TSP's stock fund held $\$ 428$ billion, with administrative expenses of only 4 basis points (Federal Retirement Thrift Investment Board 2015). No issues of government interference in the private market had arisen. The Thrift Savings Plan is relatively small, however, with equity holdings in 2015 of about 0.5 percent of total equity market value.

The Canada Pension Plan (CPP). The CPP is a defined benefit plan which pays a benefit at age 65 roughly equal to 25 percent of average indexed covered earnings. In 1997, when Canada was restoring solvency to the CPP, it made intergenerational equity - defined as each generation contributing much the same share of earnings while working and receiving benefits that replace the same share of earnings at retirement - an explicit goal. Given an aging population, this goal required the CPP to build up a large fund to help pay benefits in the future. To boost expected returns in this fund, the government recommended investing in equities.

The Canadian approach is very different than that described above for the Federal Thrift Savings Plan and for Social Security. The 1997 legislation defined an elaborate set of procedures to make the CPP Investment Board (CPPIB) as independent from the government as possible. Thus, the legislation breaks the link between government and investing by allowing the 
Board to function like a private firm. CPP assets are invested in an actively-managed portfolio, consisting of roughly 50-percent equities, 30-percent fixed income securities, and 20-percent real assets. The 1997 reformers rejected social investment and defined the sole objective of the CPPIB as acting in the best interest of plan participants - both active and retired. ${ }^{25}$ The only criticism of the CPPIB from an extensive Web search pertained to the high fees paid for active management.

Even though the United States and Canada have the same goal - to separate the government from private sector investment - the two countries have taken very different approaches. The United States would probably be more comfortable with the passive approach that has worked successfully for the Federal Thrift Savings Plan rather than setting up an independent investing entity like that in Canada.

\section{Impact on Government Finances}

Purchasing equities for the Social Security Trust Fund raises two issues with respect to government finances: 1) the potential effect of a Trust Fund buildup on national saving, and 2) the accounting treatment used to reflect the expected higher return associated with equity investment.

\section{The Saving Issue}

By itself, the introduction of equities into the Social Security program cannot ease the burden on future generations. The only way to reduce that burden is to increase national saving. More saving means more investment, increased productivity growth, and a bigger economic pie down the road. This bigger pie leaves future workers more national output after they meet the claims of the elderly. The proposal to invest a portion of Trust Fund assets in equities simply involves shifting equities from the private sector into the Social Security system and bonds from the Social Security system into the private sector. The Social Security assets would have a higher expected return with higher risk, and the private sector would have a lower expected return with lower risk. The exercise in terms of national saving is simply a "wash.”

\footnotetext{
25 The 1997 legislation also established specific rules in the event that assumed returns did not materialize. For a discussion of how these rues worked in the wake of the 2008 financial crisis, see Monk and Sass (2009).
} 
The way that the government accounts for equity investment in the budget, however, could turn what seems like a wash into increased saving by making it more difficult for Congress to spend annual Social Security surpluses. Critics claim that Congress, instead of saving the surpluses that began to accumulate in the wake of the 1983 legislation, kept taxes lower and/or spent more on non-Social-Security programs than it would have otherwise. ${ }^{26}$ Under current budget rules, investment of Trust Fund assets in corporate equities is considered an outlay. Therefore, the unified budget deficit shows higher annual spending and a larger deficit if the Trust Fund purchases equities compared with the situation when it purchases Treasury bonds. In other words, an outlay by the Trust Fund to purchase equities would reduce the size of the surplus or increase the size of the deficit compared with an outlay to purchase Treasury bonds. ${ }^{27}$ If tax and spending decisions for the non-Social-Security part of the federal budget are affected by the optics of this official budget accounting, investment of Trust Fund assets in equities might therefore affect Congressional decision-making regarding the non-Social-Security budget.

\section{The Accounting Issue}

Another issue in the debate over the introduction of equities is the thorny question of how to treat the risk in such investments when evaluating the finances of the retirement income system. Some experts argue that holding equities should reduce the projected contributions required to fund Social Security. After all, stocks yielded 6.5 percent historically, after inflation, and Treasury bills only 0.5 percent. Others maintain that the higher expected return on equities reflects their greater risk. According to this view, any serious financial evaluation of retirement arrangements should risk-adjust these expected returns. After accounting for risk, the amount of contributions needed to fund future pension obligations, or the amount of income an individual account could generate, is the same regardless of whether the assets are invested in equities or bonds.

\footnotetext{
${ }^{26}$ Smetters (2004). Economists have tried to estimate how the surpluses affected Congressional behavior, but the results are not very persuasive. Our best assessment is that, before 2000, the Social Security surpluses added to national saving. After 2000, when the entire budget appeared to be moving toward rising surpluses, the optics made large tax cuts too tempting. In other words, the Social Security surpluses may have helped enable the Bush tax cuts passed in 2001 and 2003.

${ }^{27}$ Consider the following example. Under the current arrangements in which Social Security invests solely in government bonds, if Social Security generates a surplus of $\$ 100$ billion and the rest of the budget generates a deficit of $\$ 150$ billion, the overall deficit is $\$ 50$ billion. If Social Security were to invest its $\$ 100$ billion surplus in equities, however, the outlay associated with purchasing equities would offset the program's surplus and the overall deficit would be $\$ 150$ billion.
} 
No clear consensus has emerged within the government on how to evaluate the use of equities in Social Security reform proposals. The Social Security actuaries take the first approach and credit equities with their expected rate of return. But other government agencies, like the Congressional Budget Office (CBO) and the Office of Management and Budget (OMB), ignore the higher expected return and credit equities as yielding the long-term Treasury rate. These agencies, in effect, view the cost of the additional risk in stocks as precisely offsetting their additional return.

The government confronted this issue when Congress introduced equities into the funding of the Railroad Retirement System in 2001. Congress raised benefits, reduced contributions, and sought to square the circle by authorizing investments in equities and other non-traditional assets. But OMB ignored the higher expected return on equities and used the long-term Treasury rate to project future Trust Fund balances. ${ }^{28}$ The agency clearly sought to avoid a situation where the government could appear to raise money simply by issuing debt and buying stock with the proceeds.

Adjusting for risk makes an enormous difference when assessing Social Security reform proposals that rely on equity investments. Projections using the riskless rate produce no reduction in the funding shortfall as a result of investing a portfolio of Trust Fund assets in equities. ${ }^{29}$ Thus, only an ex-post analysis will show whether stock market investment would have helped the system's financing.

\section{Conclusion}

This analysis suggests that investing a portion (a maximum of 40 percent) of Social Security Trust Fund assets in equities would reduce the need for greater employee and employer

\footnotetext{
${ }^{28}$ OMB (2003) provides a full discussion of the need to risk-adjust expected returns: "Equities and private bonds earn a higher return on average than the Treasury rate, but that return is subject to greater uncertainty. Sound budget principles require that estimates of future trust fund balances reflect both the average return and cost of risk associated with the uncertainty of that return. ... Economic theory, suggests, however, that the difference between the expected return of a risky liquid asset and the Treasury rate is equal to the cost of the asset's additional risk as priced in the market. Following through on this insight, the best way to project the rate of return on the fund's balances is to use the Treasury rate.” Most economists seem to agree on the need to risk-adjust returns when evaluating Social Security reform proposals. Geanakoplos, Mitchell, and Zeldes (1998) note that "our view is that the risk-adjusted NPV [net present value] measure is most helpful for ranking alternative" proposals. More recently, Diamond and Orszag (2004) use risk-adjusted returns to evaluate proposals that include individual accounts. Others, however, continue to embrace the "best-guess" actuarial approach (Biggs 2002).

${ }^{29}$ Option pricing techniques can also be used to calculate the risk-reward tradeoffs. See Bodie (2001).
} 
payroll tax contributions. If equity investment had begun in 1984 or 1997, Trust Funds assets would be higher than they are currently, despite two major stock market slumps and a financial crisis. Going forward, equity investment on average would help maintain a healthy Trust Fund ratio over the next 75 years.

A legitimate concern of this policy is that the government investment in equities could adversely affect the allocation of capital in the economy and corporate decision-making. There is contrary evidence, however. The experience with the Federal Thrift Savings Plan, where government plays an essentially passive role, offers a road map for separating government decision-makers from actual investment decisions. The experience of state and local pension plans highlights the need for very clear rules on social investing.

Even if some of the Social Security trust fund assets were invested in equities, the accounting provisions adopted by the Congressional Budget Office and the Office of Management and Budget would necessitate the continued use of the riskless expected rate of long-term return for evaluating the long-run financial outlook of Social Security. Thus, initiating a policy of equity investment would show no reduction in the 75-year shortfall in the near term. If equities do continue to produce superior returns over time, the positive effects would eventually be reflected in higher Trust Fund ratios than the ones we would see if Trust Fund holdings consisted solely of Treasury bonds.

In short, both prospective and ex-post analyses suggest that equities would have improved Social Security finances and that much of the concerns about interfering in private sector decisions could be addressed. 


\section{References}

Abel, Andrew B. 2001. "The Effects of Investing Social Security Funds in the Stock Market When Fixed Costs Prevent Some Households from Holding Stocks." American Economic Review 91(1): 128-148.

Advisory Council on Social Security. 1997. 1994-1996 Advisory Council on Social Security: Findings and Recommendations. Volumes I and II. Washington, DC.

Angelis, Theo. 1997. “Trust Fund Investing in Equities.” Working Paper. New Haven, CT: Yale University.

Arrow, K. J. and R. Lind. 1970. "Uncertainty and the Evaluation of Public Investment.” American Economic Review 60(3): 364-378.

Biggs, Andrew. 2002. Testimony before the Senate Finance Committee Hearing on the Final Report Produced by the President's Commission to Strengthen Social Security. October 3, 2002.

Bodie, Zvi. 2001. "Financial Engineering and Social Security Reform.” In Risk Aspects of Investment-Based Social Security Reform, edited by John Y. Campbell and Martin Feldstein, 291-290. Chicago, IL: The University of Chicago Press.

Bohn, Henning. 1999. “Social Security Reform and Financial Markets.” In Social Security Reform: Links to Saving, Investment, and Growth, edited by Steven A. Sass and Robert K. Triest, 193-241. Boston, MA: Federal Reserve Bank of Boston.

Bohn, Henning. 1999. "Should the Social Security Trust Fund Hold Equities? An Intergenerational Welfare Analysis.” Review of Economic Dynamics 2(3): 666-697.

Bohn, Henning. 2009. "Intergenerational Risk Sharing and Fiscal Policy." Journal of Monetary Economics 56 (6): 805-816.

Brown, Jeffrey R., Joshua M. Pollet, and Scott J. Weisbenner. 2015. "The In-State Equity Bias of State Pension Plans”. Working Paper 21020. Cambridge, MA: National Bureau of Economic Research.

Campbell, John Y., and Martin Feldstein. 2001. "Introduction ". In Risk Aspects of InvestmentBased Social Security Reform, pp. 1-10. University of Chicago Press.

Chetty, Raj. 2006. “A New Method of Estimating Risk Aversion.” The American Economic Review 96(5): 1821-1834.

Constantinides, George M. and Rajnish Mehra. 2003. "Junior Must Pay: Privatizing Social Security - Costs vs Benefits.” Capital Ideas 5(2). 
Damadaran, Aswath. 2015. Historical Returns on Stocks, Bonds, and Bills - United States. New York, NY: NYU Stern School of Business.

Diamond, Peter A., Alan J. Auerbach, and William G. Gale. 1997."Macroeconomic Aspects of Social Security Reform." Brookings Papers on Economic Activity 2:1-87.Washington, DC: The Brookings Institution.

Diamond, Peter A. and John Geanakoplos. 2003. "Social Security Investment in Equities.” American Economic Review 93(4): 1047-1074.

Diamond, Peter A. and Peter R. Orszag. 2003. Saving Social Security: A Balanced Approach. Washington, DC: Brookings Institution Press.

Fama, E. F. and K. R. French. 1988. "Permanent and Temporary Components of Stock Prices.” Journal of Political Economy 96: 246-273.

Federal Retirement Thrift Investment Board. 2015. "Financial Statements December 31, 2014 and 2013.” Thrift Savings Fund: Washington, DC.

Geanakoplos, John, Olivia S. Mitchell, and Stephen P. Zeldes. 1999. “Social Security Money’s Worth.” In Prospects for Social Security Reform, edited by Oliva S. Mitchell, Robert J. Myers, and Howard Young, 79-151. Philadelphia, PA: University of Pennsylvania Press.

Gollier, Christian. 2008. “Intergenerational Risk-Sharing and Risk-Taking of a Pension Fund.” Journal of Public Economics 92(5-6): 1463-1485.

Mankiw, N. Gregory, and Stephen P. Zeldes. 1991. "The Consumption of Stockholders and Nonstockholders." Journal of Financial Economics 29(1): 97-112.

Mehra, Rajnish. 2003. “The Equity Premium: Why is it a Puzzle?” Financial Analysts Journal 59(1):55-69

Monk, Ashby H. B. and Steven A. Sass. 2009. "Risk Pooling and the Market Crash: Lessons from Canada’s Pension Plan.” Issue in Brief 9-12. Chestnut Hill, MA: Center for Retirement Research at Boston College.

Munnell, Alicia H. and Pierluigi Balduzzi. 1998. "Investing the Social Security Trust Funds in Equities.” AARP Working Paper 9802. Washington, DC: AARP.

Munnell, Alicia H. 2007. “Should Public Plans Engage in Social Investing?” Issue in Brief 7-12. Chestnut Hill, MA: Center for Retirement Research at Boston College.

Munnell, Alicia H and Anqi Chen. 2016. "New Developments in Social Investing by Public Pension Plans” State and Local Pensions \# 53. Chestnut Hill, MA: Center for Retirement Research at Boston College. 
Office of the Chief Actuary, Office of the Superintendent of Financial Institutions Canada. 2013. 26th Actuarial Report on the Canada Pension Plan as at 31 December 2012. Ottawa: Minister of Public Works and Government Services.

Ostazewski, Krzystof M. 1997. "Privatizing the Social Security Trust Fund? Don’t Let the Government Invest.” Social Security Choice Paper No. 6. Washington, DC: The Cato Institute.

Poterba, James P. and Lawrence H. Summers. 1988. "Mean Reversion in Stock Prices: Evidence and Implications.” Journal of Financial Economics 22: 27-59.

Smetters, Kent. 2004. "Is the Social Security Trust Fund a Store of Value?" American Economic Review 94(2): 176-181.

Starmer, Chris. 2000. "Developments in non-expected utility theory: The hunt for a descriptive theory of choice under risk." Journal of Economic Literature 38(2): 332-382.

U.S. Office of Management and Budget. 2003. Budget of the United States - Fiscal Year 2003. Budget System and Concepts. Washington, DC.

U.S. Social Security Administration. 2015. "Solvency Provisions” Available at: https://www.ssa.gov/oact/solvency/provisions_tr2015/charts/chart_run124.html\#graph 
Table 1. Average Returns and Standard Deviation of Different Assets, 1928-2016

\begin{tabular}{lccc}
\hline & $\begin{array}{c}\text { Average } \\
\text { geometric returns }\end{array}$ & Standard deviation & Growth of $\$ 100$ \\
\hline S\&P 500 & $9.5 \%$ & 19.7 & $\$ 328,584$ \\
3-month Treasury Bill & 3.4 & 3.0 & 1,988 \\
10- year Treasury Bond & 4.9 & 7.7 & 7,111 \\
\hline
\end{tabular}

Source: Authors' calculations from Damadaran (2016).

Table 2. Historical and Projected Returns, 1929-2016 and 2017-2090

\begin{tabular}{lccc}
\hline & $\begin{array}{c}\text { Actual } \\
1929-2016\end{array}$ & $\begin{array}{c}\text { Projection } \\
2016-2089\end{array}$ & $\begin{array}{c}\text { Central } \\
\text { Assumptions } \\
2016-2089\end{array}$ \\
\hline Nominal equity returns $^{1}$ & $9.5 \%$ & $6.2-7.0 \%$ & $6.6 \%$ \\
Inflation $^{\text {Real equity returns }}{ }^{1}$ & 3.0 & 2.7 & 2.7 \\
3 mo. T-bill & 6.5 & $3.5-4.3$ & 3.9 \\
Equity premium $^{1}$ & 0.4 & 0.4 & 0.4 \\
& 6.1 & $3.1-4.1$ & 3.5 \\
\hline
\end{tabular}

${ }^{1}$ Based on the Hypothetical Wilshire 5000.

Source: Authors' calculations.

Table 3. OASDI Trust Fund Ratio with Equity Investment, Under Different Phase-Ins and a 40Percent Equity Ceiling, 2016

\begin{tabular}{lcccc}
\hline Equity investment start year & Actual & 2.00 percent & 2.67 percent & 5.00 percent \\
\hline 1984 & 3.0 & 4.1 & 4.2 & 4.4 \\
1997 & 3.0 & 3.7 & 3.8 & 3.7 \\
\hline
\end{tabular}

Source: Authors' calculations.

Table 4. OASDI Trust Fund Ratio with Equity Investment, Under a 2.67-Percent Phase-In and Different Equity Ceilings, 2016

\begin{tabular}{lcrcc}
\hline Equity investment start year & Actual & 20 percent & 40 percent & 60 percent \\
\hline 1984 & 3.0 & 3.7 & 4.2 & 4.6 \\
1997 & 3.0 & 3.4 & 3.8 & 3.9 \\
\hline
\end{tabular}

Source: Authors' calculations. 
Table 5. First Calendar Year in which Trust Fund Ratio Falls Below 1.0 or Assets Are Exhausted, Under Different Portfolios

\begin{tabular}{lcc}
\hline & Trust Fund ratio $<1$ & Exhausted \\
\hline Bond-only & 2059 & 2072 \\
Mixed & 2042 & 2064 \\
\hline
\end{tabular}

Source: Authors’ calculations. 
Figure 1. Social Security’s 75-Year Deficit as a Percentage of Taxable Payroll, 1983-2016

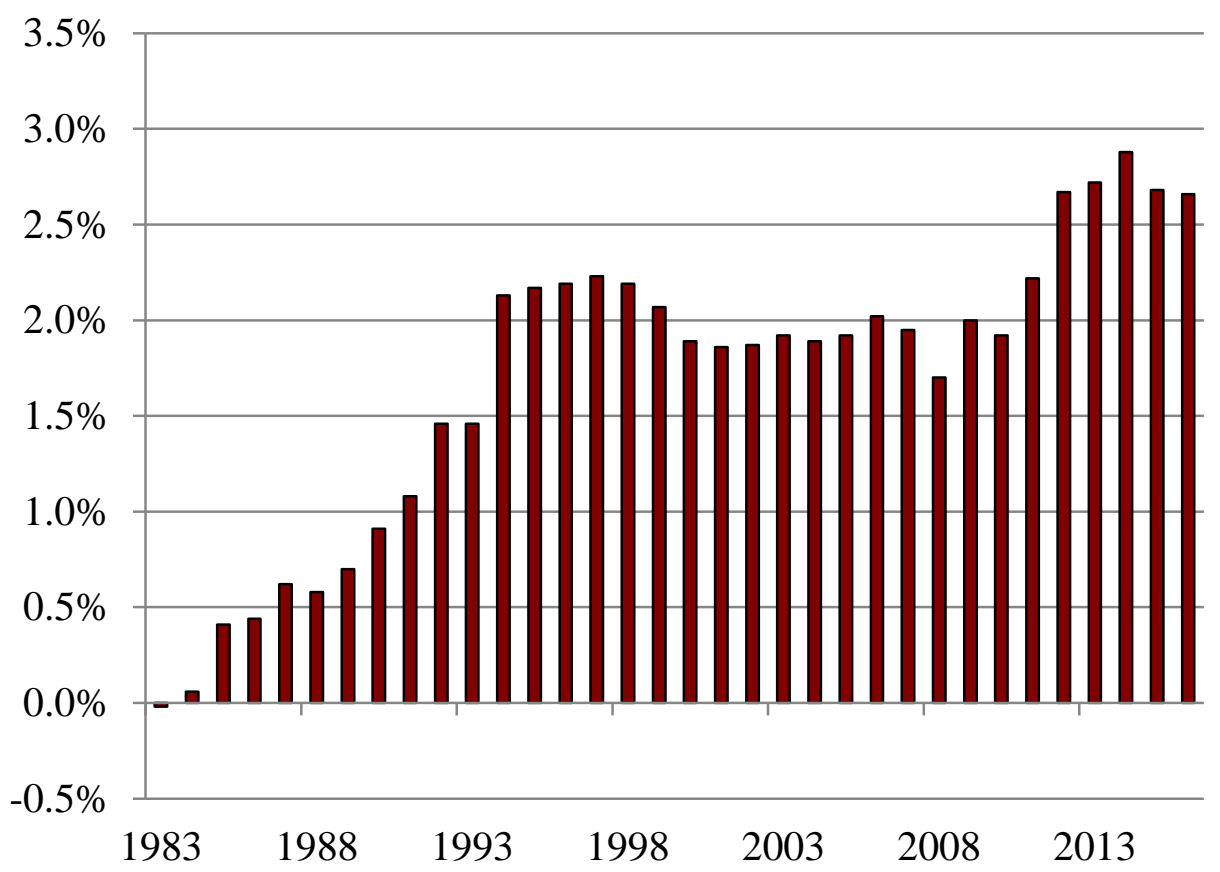

Source: Social Security Trustees Report (1983-2016).

Figure 2. Projected Trust Fund Ratio, Under Different Portfolios, 2017-2091

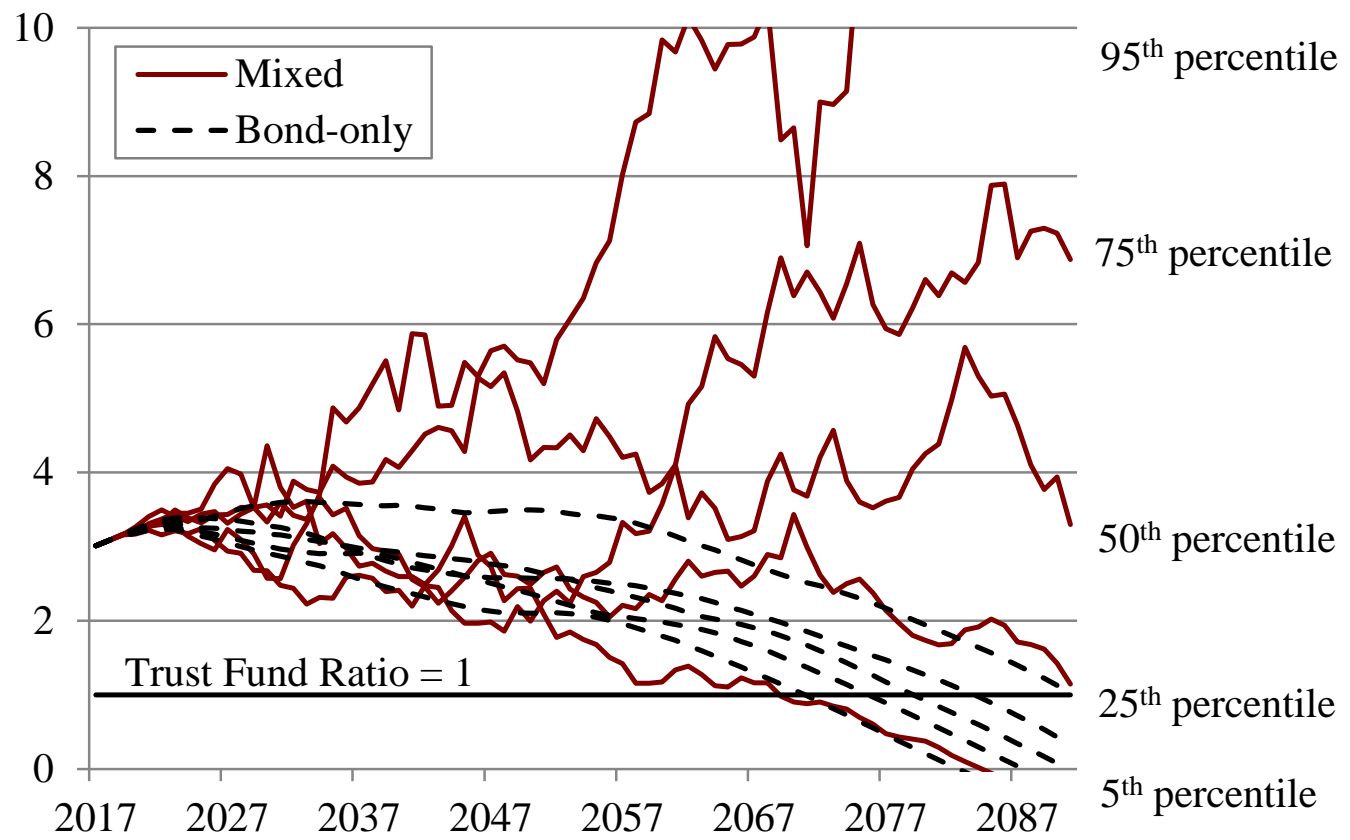

Note: The percentiles of the simulations are determined by the rank of outcomes in 2091. The paths follow the movement of these simulations along the 75-year projection horizon. For simulations in which the Trust Fund is exhausted, the simulation is halted at the point of exhaustion.

Source: Authors' calculations. 
Figure 3. Percentage of Simulations Across 75-year Horizon in Which Trust Fund Assets Drop to Specified Levels, Under Different Portfolios

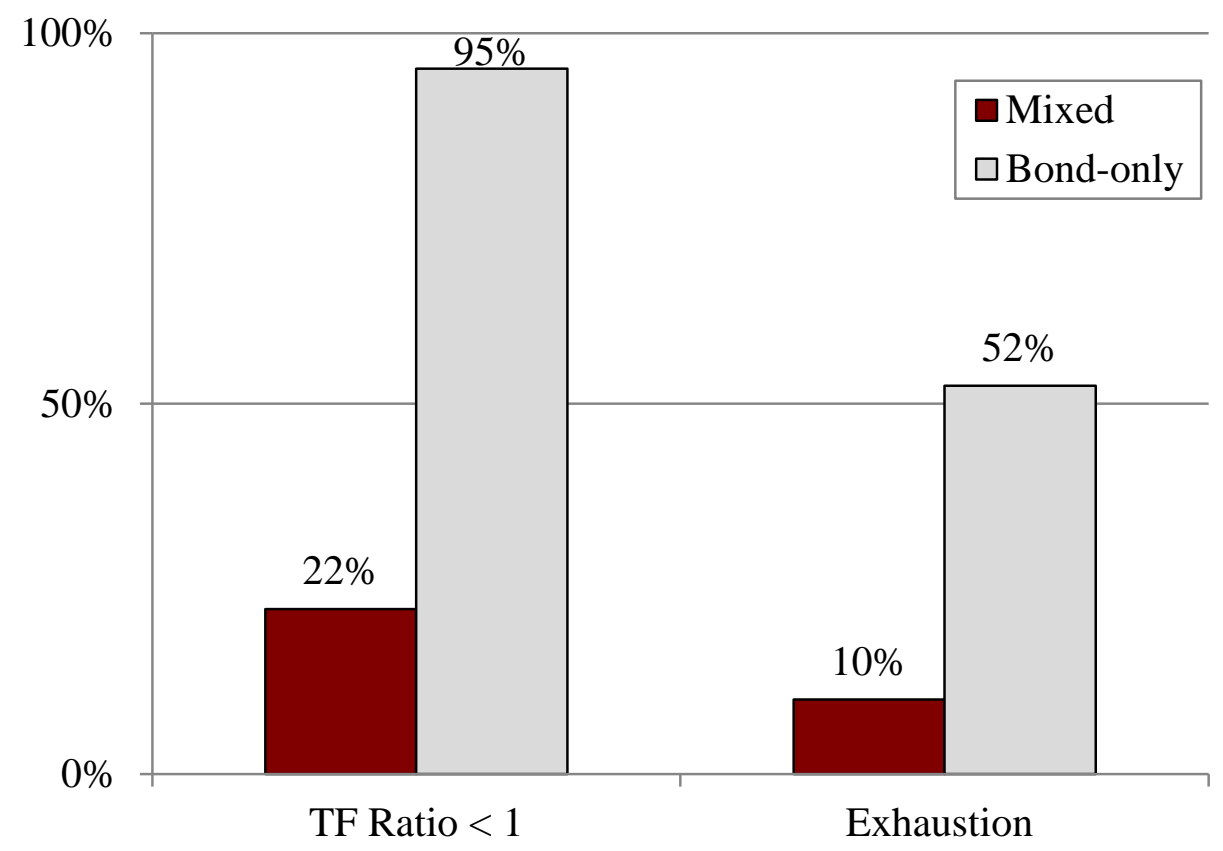

Source: Authors' calculations.

Figure 4. Increases in "Tax Refunds" and "Back Taxes" Due to Shift from Bond-Only to Mixed Portfolio

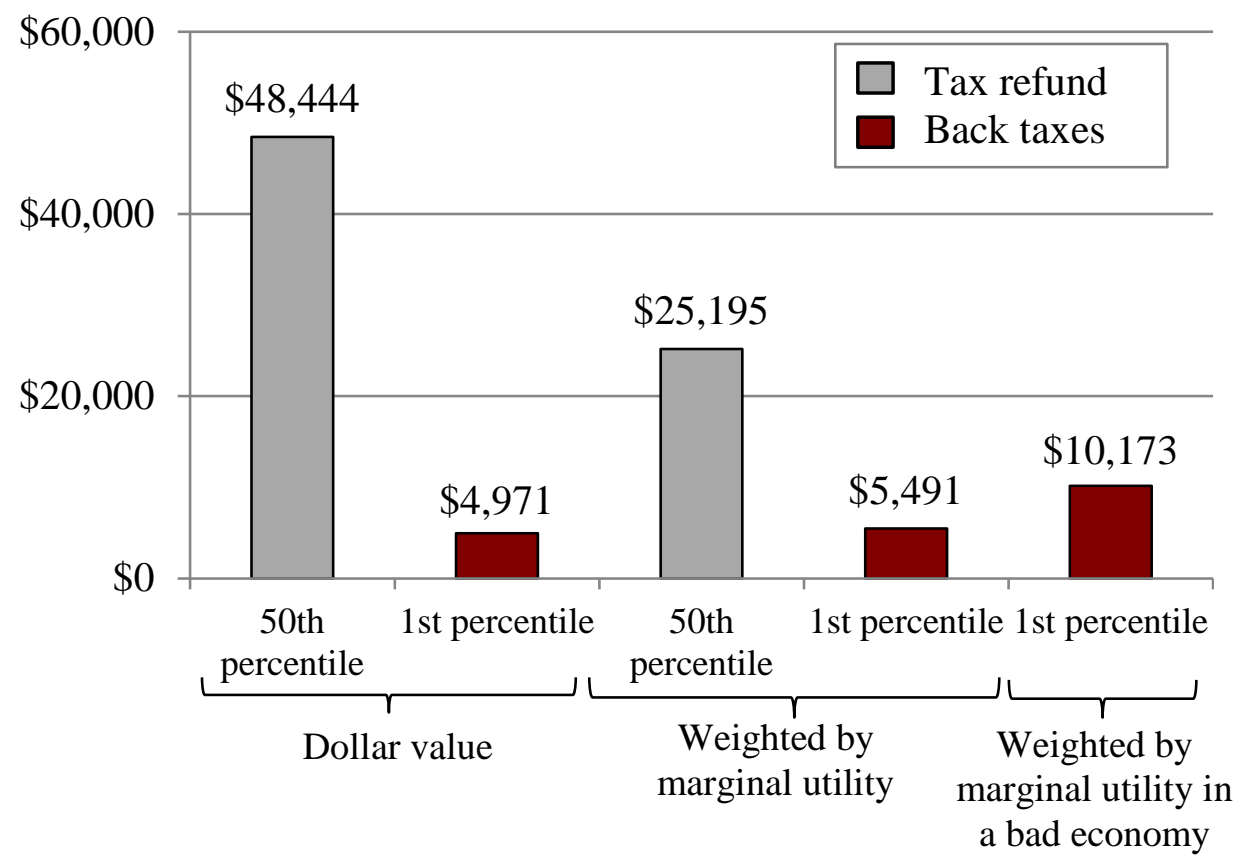

Source: Authors' calculations. 
Figure 5. Percentage of Total Equities Held by the Trust Fund, 1984-2016

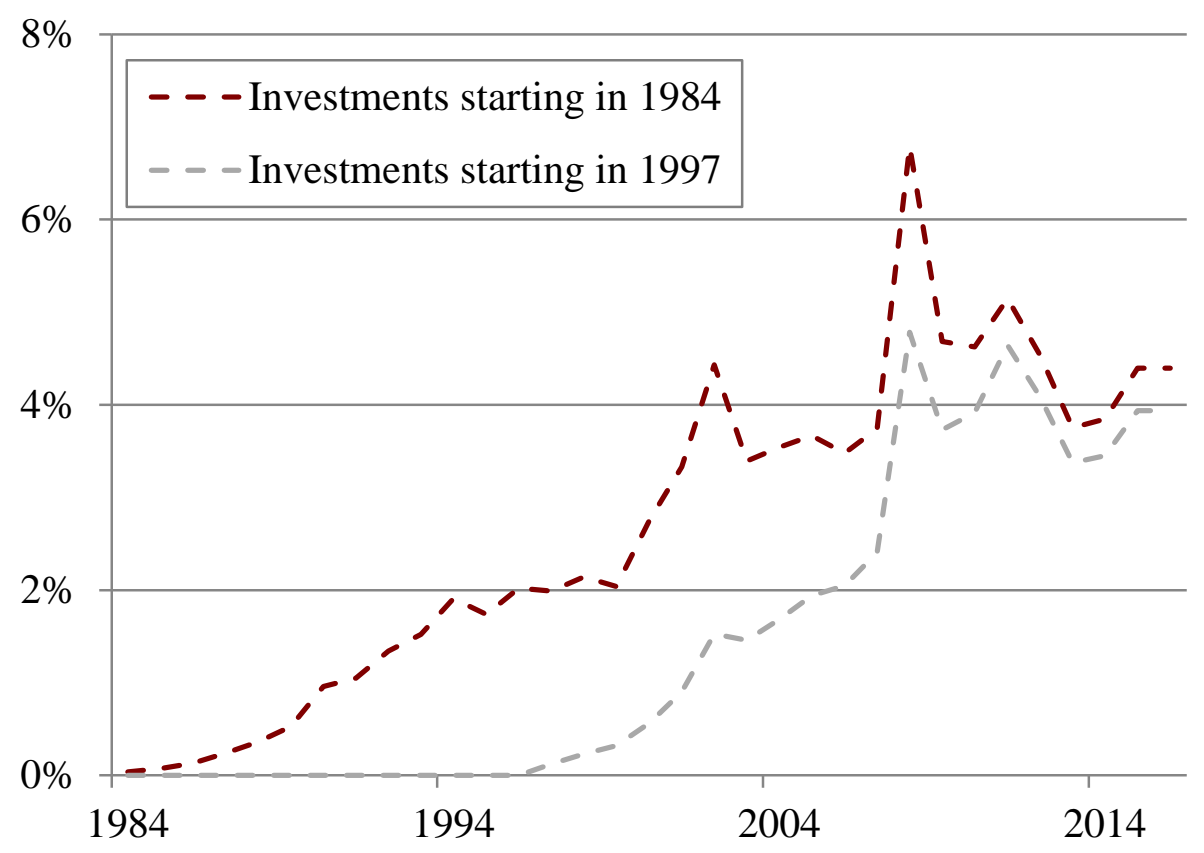

Source: Authors’ calculations.

Figure 6. Percentage of Total Equities Held by the Trust Fund, 2017-2091

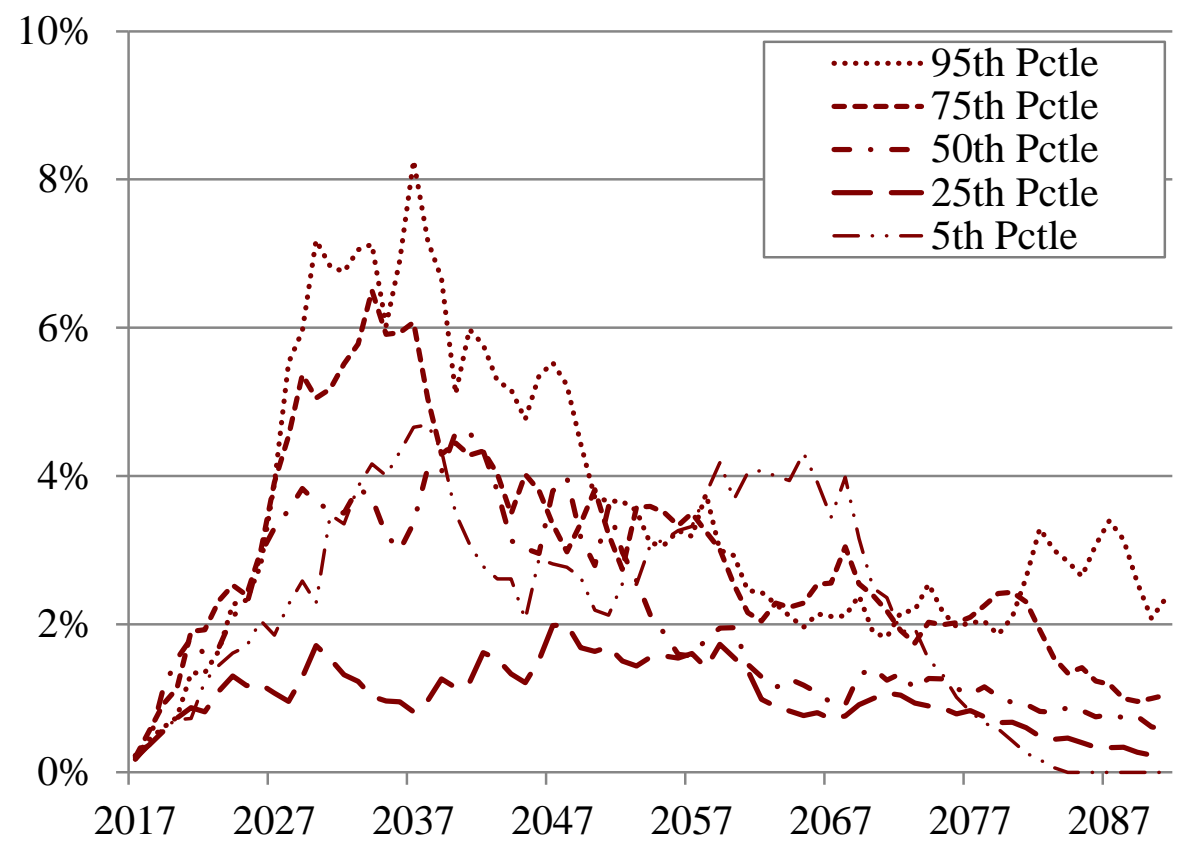

Note: The percentiles are ranked based on the percentage of total equities held by the Trust Fund at the end of the projection horizon.

Source: Authors' calculations. 


\section{Appendix}

Table A1. Bond and Equity Purchases as a Percentage of GDP Under Different Equity Ceilings, Investments Starting in 1984

\begin{tabular}{|c|c|c|c|c|c|c|c|}
\hline \multirow{2}{*}{ Year } & \multirow{2}{*}{$\begin{array}{c}\text { Actual } \\
\text { bond } \\
\text { purchases }\end{array}$} & \multicolumn{2}{|c|}{20 percent } & \multicolumn{2}{|c|}{40 percent } & \multicolumn{2}{|c|}{60 percent } \\
\hline & & $\begin{array}{c}\text { Bond } \\
\text { purchases }\end{array}$ & $\begin{array}{c}\text { Equity } \\
\text { purchases }\end{array}$ & $\begin{array}{c}\text { Bond } \\
\text { purchases }\end{array}$ & $\begin{array}{c}\text { Equity } \\
\text { purchases }\end{array}$ & $\begin{array}{c}\text { Bond } \\
\text { purchases }\end{array}$ & $\begin{array}{c}\text { Equity } \\
\text { purchases }\end{array}$ \\
\hline 1984 & $0.2 \%$ & $0.1 \%$ & $0.0 \%$ & $0.1 \%$ & $0.0 \%$ & $0.1 \%$ & $0.0 \%$ \\
\hline 1985 & 0.3 & 0.2 & 0.0 & 0.2 & 0.0 & 0.2 & 0.0 \\
\hline 1986 & 0.1 & 0.2 & 0.0 & 0.2 & 0.0 & 0.2 & 0.0 \\
\hline 1987 & 0.4 & 0.3 & 0.1 & 0.3 & 0.1 & 0.3 & 0.1 \\
\hline 1988 & 0.8 & 0.6 & 0.1 & 0.6 & 0.1 & 0.6 & 0.1 \\
\hline 1989 & 0.9 & 0.7 & 0.1 & 0.7 & 0.1 & 0.7 & 0.1 \\
\hline 1990 & 1.0 & 0.5 & 0.2 & 0.5 & 0.2 & 0.5 & 0.2 \\
\hline 1991 & 0.9 & 0.5 & 0.0 & 0.5 & 0.0 & 0.5 & 0.0 \\
\hline 1992 & 0.8 & 0.4 & 0.0 & 0.4 & 0.0 & 0.4 & 0.0 \\
\hline 1993 & 0.7 & 0.2 & 0.0 & 0.2 & 0.0 & 0.2 & 0.0 \\
\hline 1994 & 0.8 & 0.2 & 0.2 & 0.2 & 0.2 & 0.2 & 0.2 \\
\hline 1995 & 0.8 & 0.5 & -0.2 & 0.6 & -0.3 & 0.6 & -0.3 \\
\hline 1996 & 0.9 & 0.5 & -0.1 & 0.5 & -0.1 & 0.5 & -0.1 \\
\hline 1997 & 1.0 & 0.7 & -0.2 & 0.7 & -0.2 & 0.7 & -0.2 \\
\hline 1998 & 1.2 & 0.7 & 0.0 & 0.7 & 0.0 & 0.7 & 0.0 \\
\hline 1999 & 1.4 & 0.9 & -0.1 & 0.9 & -0.1 & 0.9 & -0.1 \\
\hline 2000 & 1.5 & 0.5 & 0.4 & 0.1 & 0.7 & 0.1 & 0.8 \\
\hline 2001 & 1.5 & 0.3 & 0.5 & 0.0 & 0.9 & -0.1 & 1.0 \\
\hline 2002 & 1.5 & 0.1 & 0.6 & -0.3 & 1.1 & -0.4 & 1.2 \\
\hline 2003 & 1.3 & 0.9 & -0.3 & 0.9 & -0.3 & 0.8 & -0.3 \\
\hline 2004 & 1.3 & 0.6 & -0.1 & 0.6 & -0.1 & 0.5 & 0.0 \\
\hline 2005 & 1.3 & 0.5 & 0.0 & 0.5 & 0.1 & 0.4 & 0.2 \\
\hline 2006 & 1.4 & 0.7 & -0.1 & 0.7 & -0.1 & 0.6 & 0.0 \\
\hline 2007 & 1.3 & 0.5 & 0.1 & 0.4 & 0.2 & 0.3 & 0.3 \\
\hline 2008 & 1.2 & -0.8 & 1.3 & -1.6 & 2.1 & -1.8 & 2.2 \\
\hline 2009 & 0.8 & 0.7 & -0.7 & 1.1 & -1.0 & 1.0 & -0.9 \\
\hline 2010 & 0.5 & 0.1 & -0.4 & 0.3 & -0.6 & 0.4 & -0.7 \\
\hline 2011 & 0.4 & -0.3 & 0.0 & -0.3 & 0.0 & -0.3 & 0.0 \\
\hline 2012 & 0.3 & 0.1 & -0.4 & 0.4 & -0.7 & 0.4 & -0.7 \\
\hline 2013 & 0.2 & 0.4 & -0.9 & 1.0 & -1.4 & 1.0 & -1.5 \\
\hline 2014 & 0.1 & 0.0 & -0.4 & 0.3 & -0.7 & 0.4 & -0.8 \\
\hline 2015 & 0.1 & -0.4 & -0.1 & -0.3 & -0.2 & -0.2 & -0.3 \\
\hline 2016 & 0.1 & -0.1 & -0.3 & 0.1 & -0.5 & 0.2 & -0.6 \\
\hline
\end{tabular}

Note: The maturity structures of the bonds held by the Trust Fund are not accounted for. The portfolio is assumed to be rebalanced at the end of every year. GDP is provided by the 2016 Trustees Report.

Source: Author's calculations. 
Figure A1. OASDI Trust Fund Ratio with Equity Investment starting in 1984 and 1997

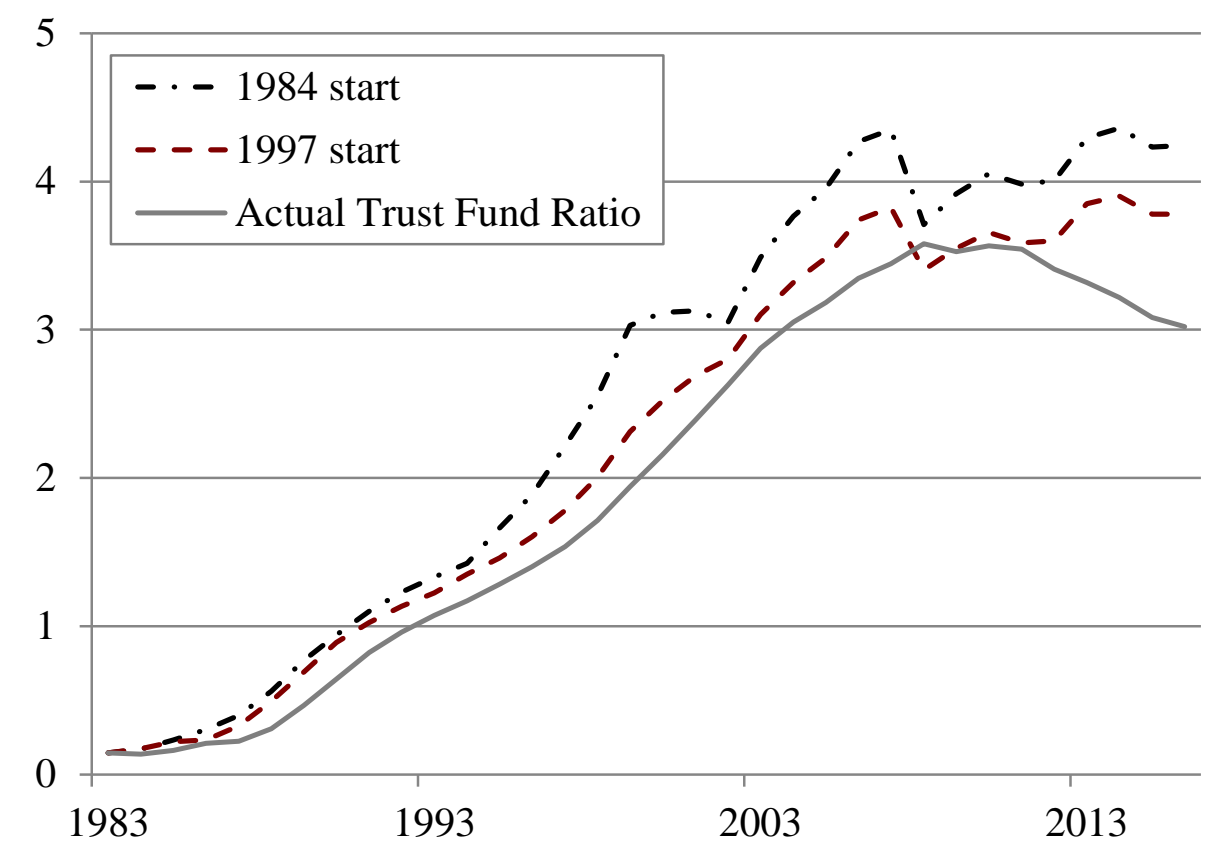

Source: Authors' calculations.

Figure A2. OASDI Trust Fund Ratio with Equity Investment Starting in 1984, Under a 2.67Percent Phase-In and Different Equity Ceilings

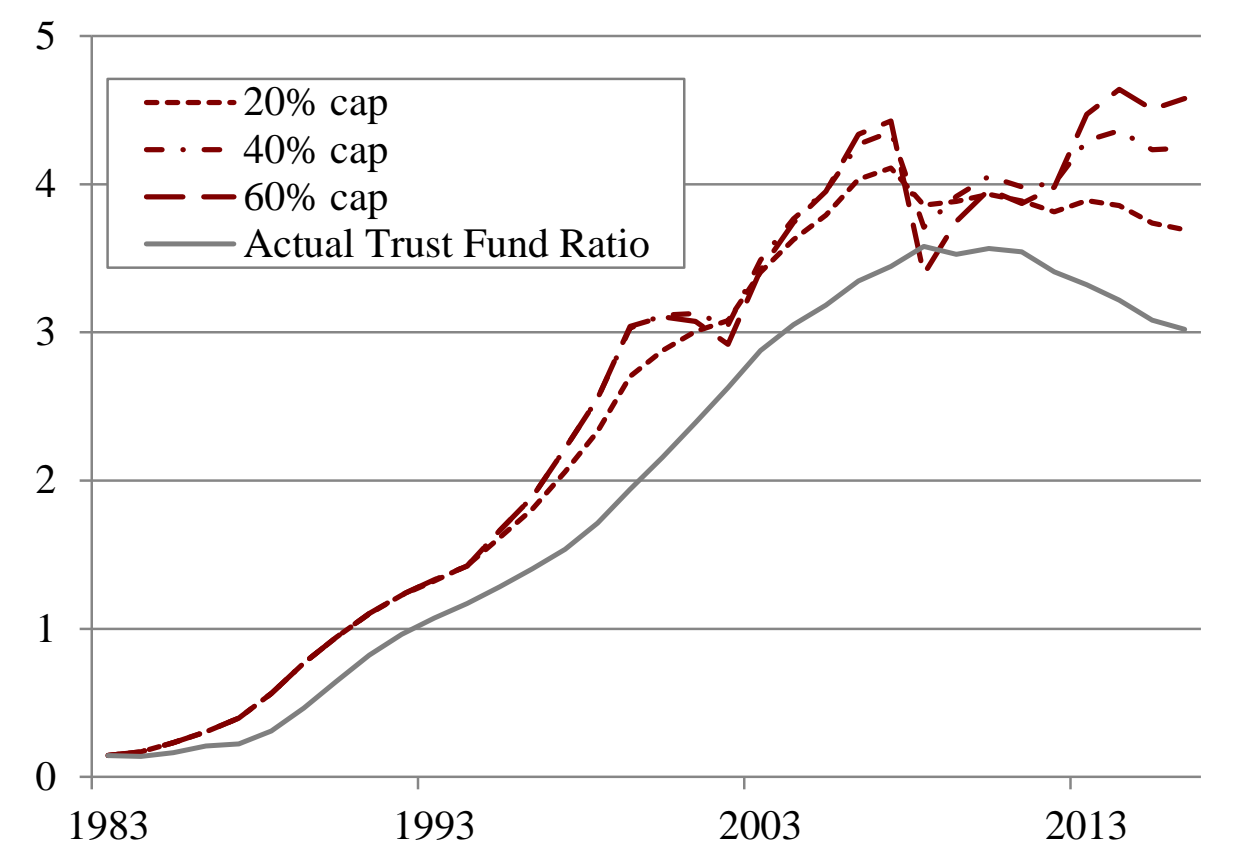

Source: Authors' calculations. 
Figure A3. OASDI Trust Fund Ratio with Equity Investment Starting in 1997, Under a 2.67Percent Phase-In and Different Equity Ceilings

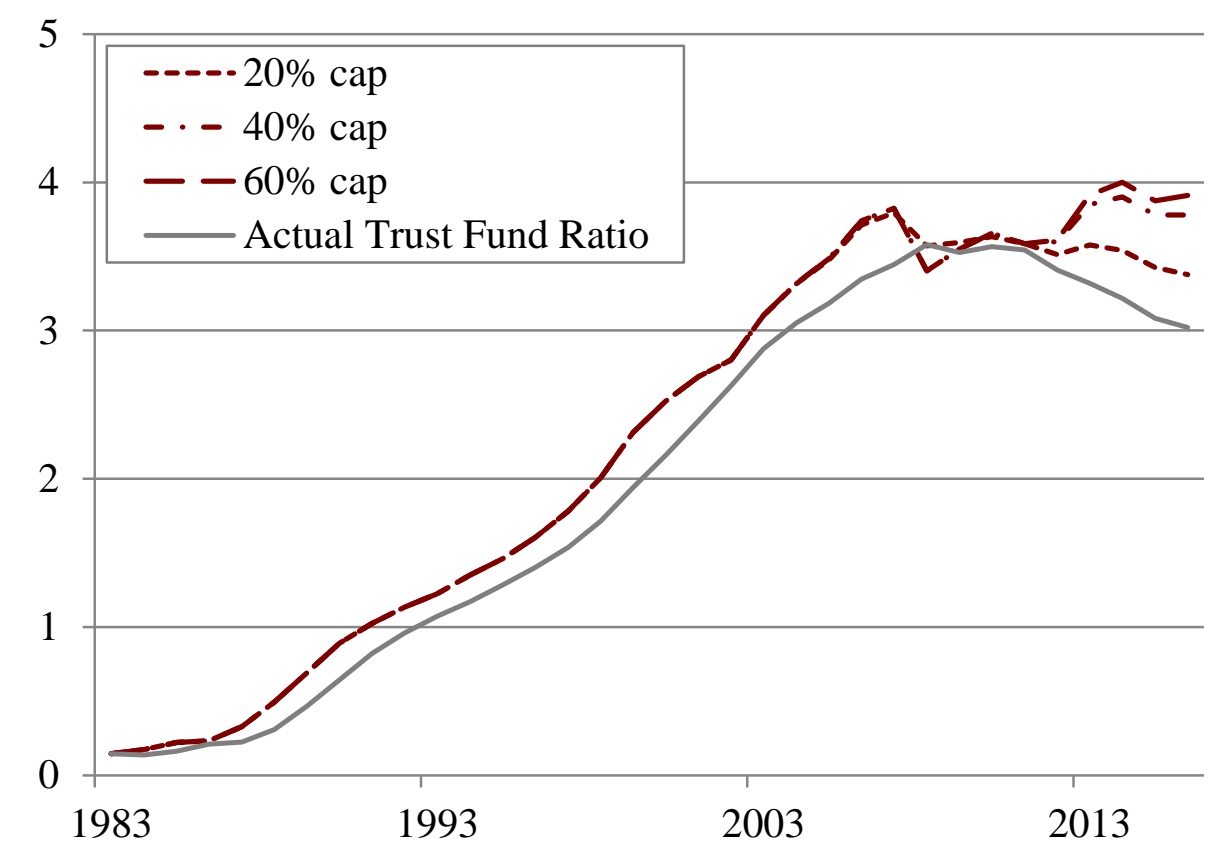

Source: Authors' calculations.

Figure A4. OASDI Trust Fund Ratio with Equity Investment Starting in 1984 with Immediate Phase-In, Under Different Equity Ceilings

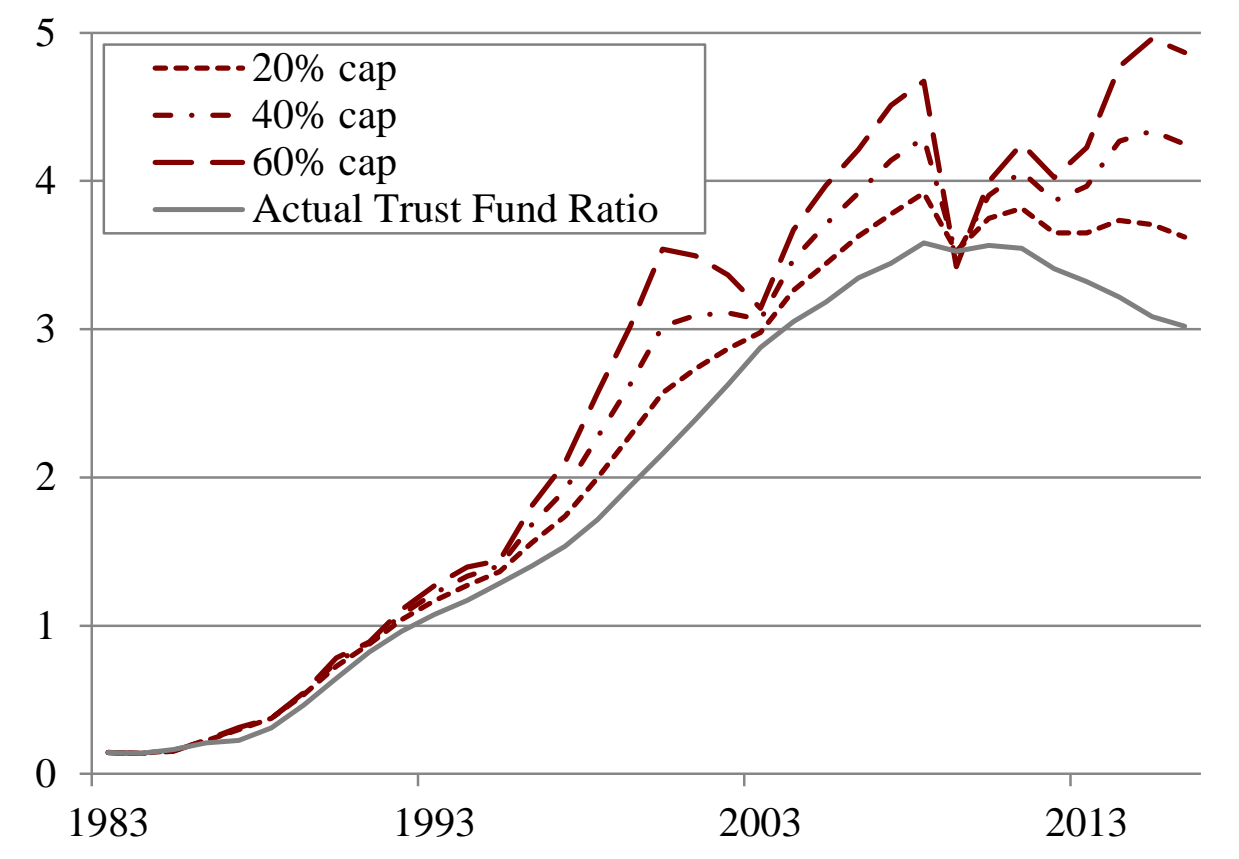

Source: Authors’ calculations. 
Figure A5. Projected Trust Fund Ratio Assuming Equity Returns Center Around 3.5\%, Under Different Portfolios, 2017-2091

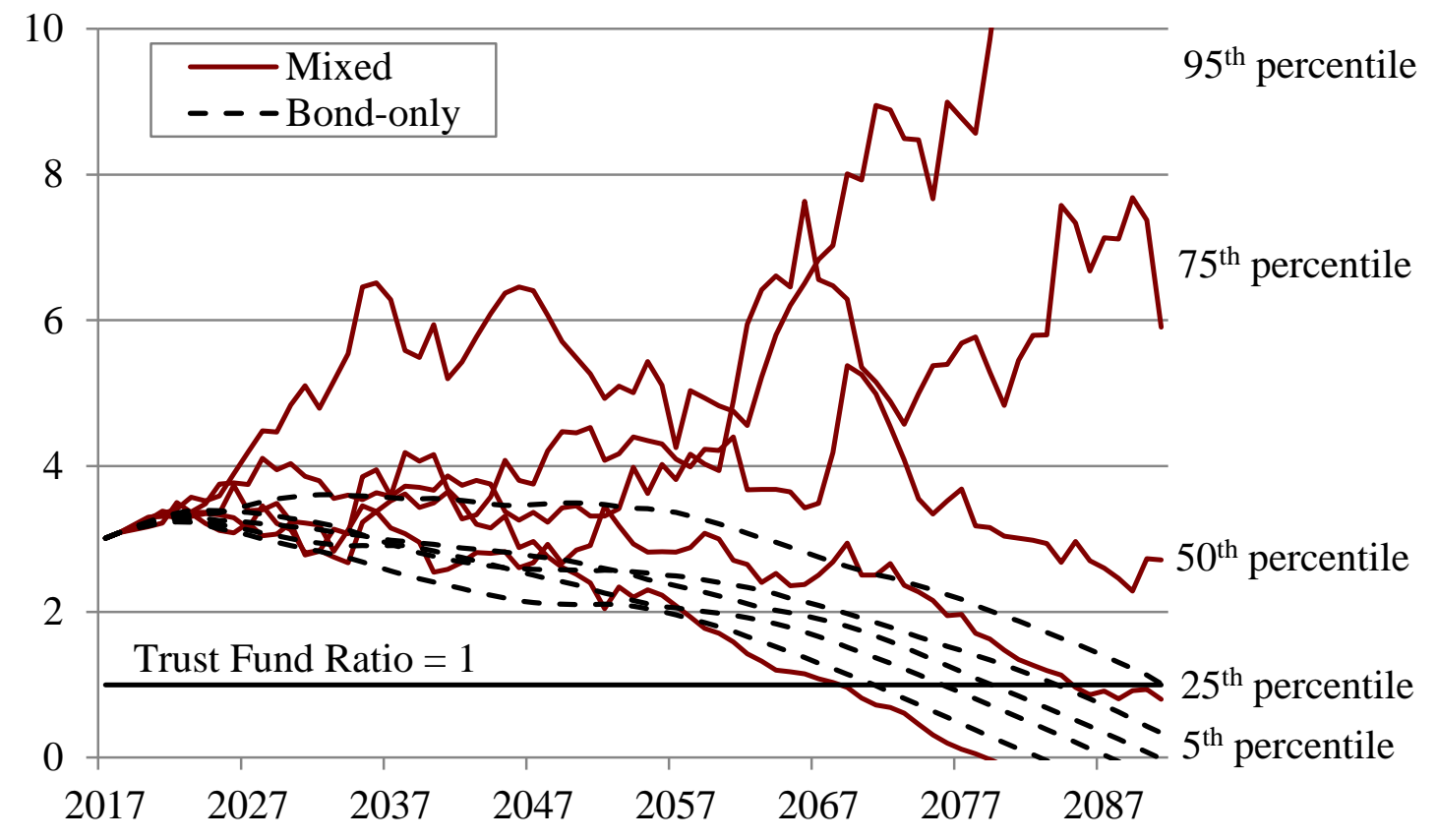

Source: Authors' calculations.

Figure A6. Projected Trust Fund Ratio Assuming Equity Returns Center Around 4.3\%, Under Different Portfolios, 2017-2091

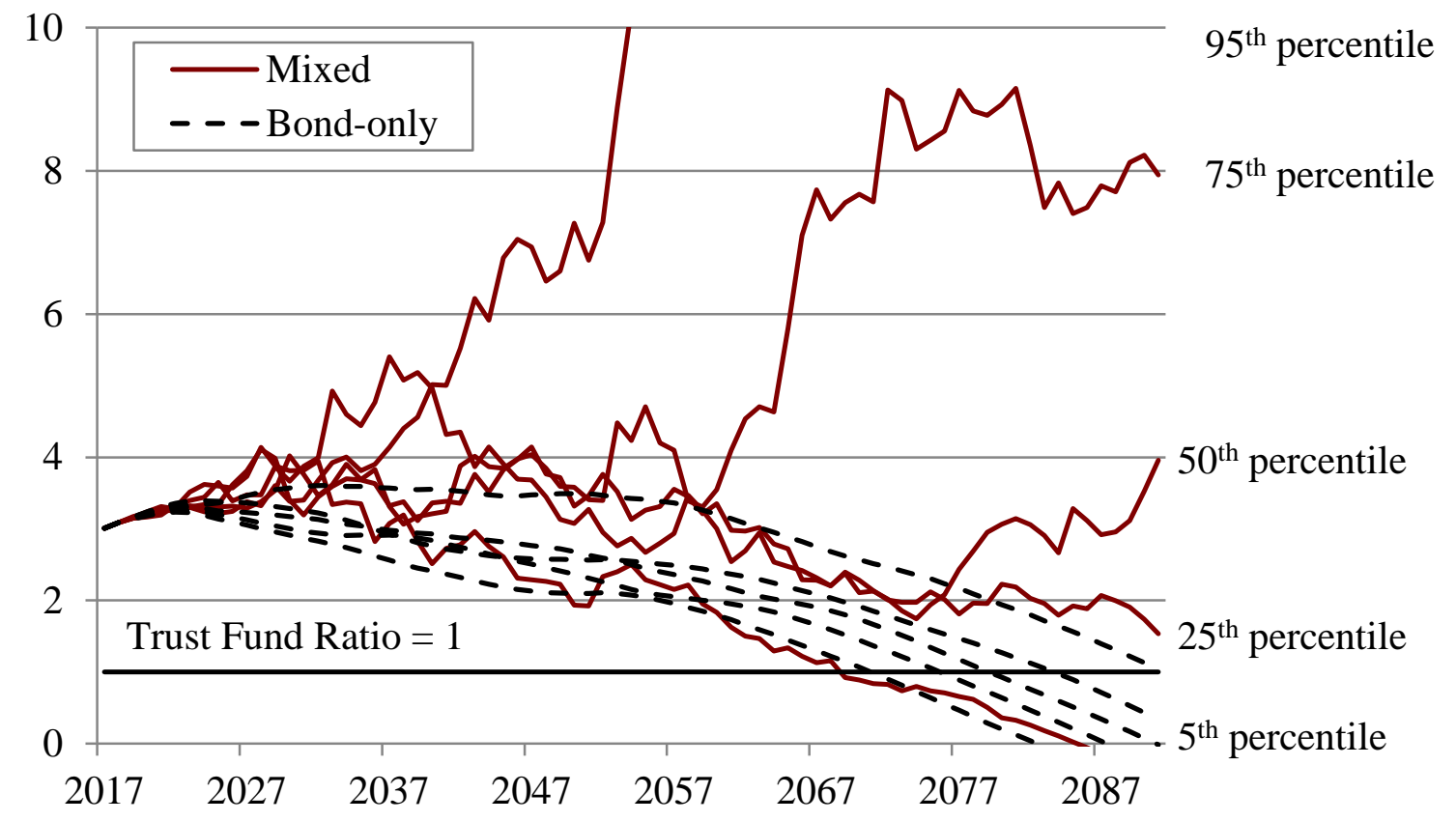

Source: Authors' calculations. 